The Israeli Journal of Aquaculture - Bamidgeh, IIC:63.2011.606, 7 pages

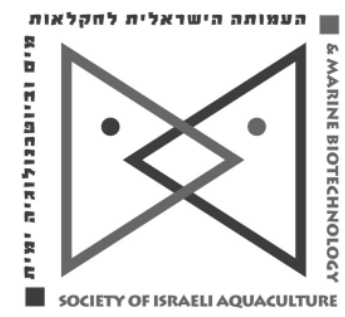

The IJA appears exclusively as a peer-reviewed on-line open access journal at http://www.siamb.org.il

Sale of IJA papers is strictly forbidden.

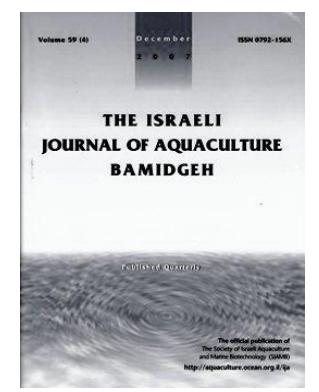

\title{
Growth and Feed Efficiency in Mangrove Red Snapper, (Lutjanus argentimaculatus Forsskal 1775) Fed Practical Diets Supplemented with L-ascorbyl-2-monophosphate-Mg
}

\author{
Mae R. Catacutan ${ }^{1} *$, Gregoria E. Pagador ${ }^{1}$, Ellen Doyola-Solis ${ }^{1}$, \\ Shinichi Teshima², Manabu Ishikawa ${ }^{2}$ \\ ${ }^{1}$ Aquaculture Department, Southeast Asian Fisheries Development \\ Center, Tigbauan, Iloilo, Philippines 5021 \\ ${ }^{2}$ Laboratory of Aquatic Animal Nutrition, Kagoshima University Faculty of \\ Fisheries, Shimoarata, Kagoshima City, Japan
}

(Received 2.7.10, Accepted 2.9.10)

Key words: snapper, growth, L-ascorbyl-2-monophosphate -Mg, kidney and liver histology

\begin{abstract}
Growth and feed efficiency were determined in red snapper, Lutjanus argentimaculatus (Forsskal 1775), fed diets containing L-ascorbyl-2monophosphate-Mg (AMP). Fish $(13.39 \pm 0.08 \mathrm{~g})$ were fed a practical diet without vitamin C supplement for four weeks then stocked in twelve 650-I tanks at 30 fish/tank and fed one of four practical diets containing AMP at 0 , 60,180 , or $540 \mathrm{mg} / \mathrm{kg}$ dry diet for 17 weeks. Survival rates in all treatments were similar (88.9-98.9\%). Fish fed the 0 or $540 \mathrm{ppm}$ diets had inferior final average weights, protein efficiency ratios, and feed conversion ratios than fish fed the 60 or $80 \mathrm{ppm}$ diets $(p<0.05)$. Growth of fish fed the 0 or $540 \mathrm{ppm}$ diets slowed down on day 60 and fish fed the AMP-free diet exhibited clinical signs of vitamin $C$ deficiency with a soft body and a significantly high $(p<0.05)$ hepatosomatic index. Ascorbic acid in brain and liver tissues rose with the level of dietary AMP. Fish fed the $540 \mathrm{ppm}$ diet had significantly lower hematocrit $(p<0.05)$ than fish fed the 60 or $180 \mathrm{ppm}$ diets. Histological analysis of the liver and kidney of fish fed the 180 and $540 \mathrm{ppm}$ diets showed changes indicative of possible toxic effects. Based on growth, feed efficiency, tissue histology, and hematocrit level, AMP at $540 \mathrm{ppm}$ is toxic to snapper. Thus, supplementation of $60 \mathrm{ppm}$ AMP or its equivalent $26 \mathrm{ppm}$ ascorbic acid in practical diets for red snapper promotes optimum growth and feed efficiency and prevents vitamin C deficiency symptoms.
\end{abstract}

\footnotetext{
* Corresponding author. Tel.: +63-33-336-2965, fax: +63-33-511-9070, e-mail: mrc@seafdec.org.ph
} 


\section{Introduction}

The Indo-West Pacific red snapper (Lutjanus argentimaculatus Forsskal 1775) is a popular species for culture. Thus, reports are available on red snapper reproduction in captivity (Leu et al., 2003; Ibara-Castro and Lajonchere, 2009), maturation and seed production using natural food organisms (Duray et al., 1996), dietary crude protein requirement $(44 \%)$ and protein to energy ratio $(23.3 \mathrm{mg}$ protein/ $\mathrm{kJ}$ ) for grow-out size snapper (Catacutan et al., 2001), and the optimum inclusion level of defatted soybean meal $(24 \%)$ in the snapper diet (Catacutan and Pagador, 2004). These are important factors in developing formulated red snapper feed that is more convenient and practical to use than trash fish. The efficiency of formulated artificial feeds can be enhanced by cost-effective supplements of essential micronutrients.

Labile vitamin $\mathrm{C}$ is an important micronutrient. L-ascorbyl-2-monophosphate-Mg (AMP), a stable phosphate derivative of vitamin $C$ that remains stable during feed manufacture, meets the vitamin C requirements of seabass Lates calcarifer (Phromkunthong et al., 1997), grouper Epinephelus malabaricus (Lin and Shiau, 2005), and ayu fish (Plecoglossus altivelis; Xie and Niu, 2006). Our study was designed to investigate growth and feed efficiency, examine changes in kidney and liver histology, and determine the vitamin $C$ content in the brain and kidney in mangrove red snapper fed practical feed ingredients supplemented with different levels of AMP.

\section{Materials and Methods}

Fish. Red snapper (Lutjanus argentimaculatus) fry were obtained from the SEAFDEC/AQD hatchery in Tigbauan, Iloilo, Philippines, and reared in 650-I fiberglass tanks with aerated sand-gravel filtered sea water (salinity $32 \mathrm{~g} / \mathrm{l}$, flow rate $1-2 \mathrm{l} / \mathrm{min}$ ). Fry were fed Artemia for two weeks and gradually weaned during three weeks until they were able to subsist solely on a dry pelleted maintenance diet ( $45 \%$ protein).

Diets. Four experimental diets were formulated from a basal diet $(45.4 \%$ crude

Table 1. Composition ( $\mathrm{g} / \mathrm{kg}$ dry diet) of test diets*.

\begin{tabular}{|c|c|c|c|c|}
\hline \multirow[b]{2}{*}{ Ingredient } & \multicolumn{4}{|c|}{ AMP content ( $\mathrm{mg} / \mathrm{kg}$ diet $)$} \\
\hline & 0 & 60 & 180 & 540 \\
\hline Peruvian fishmeal & 450 & 450 & 450 & 45 \\
\hline Acetes sp. & 70 & 70 & 70 & \\
\hline Squid meal & 50 & 50 & 50 & \\
\hline Defatted soybean meal & 80 & 80 & 80 & \\
\hline Breadflour & 200 & 200 & 200 & 20 \\
\hline Cod liver oil & 38 & 38 & 38 & \\
\hline Soybean lecithin & 5 & 5 & 5 & \\
\hline Vitamin mix ${ }^{1}$ & 15 & 15 & 15 & \\
\hline Mineral $\operatorname{mix}^{2}$ & 20 & 20 & 20 & \\
\hline Dicalphos ${ }^{3}$ & 5 & 5 & 5 & \\
\hline AMP 4 & 0 & 0.06 & 0.18 & 0.5 \\
\hline Rice bran & 67 & 66.94 & 66.82 & 66.4 \\
\hline
\end{tabular}

* Moisture averaged $4.4 \%$. On a dry matter basis, crude protein $=45.4 \%$, crude fat $=9.3 \%$, crude fiber $=1.7 \%$, ash $=13.8 \%$, nitrogen free extract $=$ $29.8 \%$.

${ }^{1} \mathrm{mg} / \mathrm{kg}$ dry diet: beta-carotene 6 , cholecalciferol 3, DL-alphatocopherol 200, menadione 33, paraaminobenzoic acid 200, biotin 3, Ca-pantothenate 140 , choline chloride 4000, cyanocobalamin 0.045 , folic acid 0.75 , inositol 2000 , niacin 400 , pyridoxine 20 , riboflavin 100 , thiamin 30 , celufil 7864.205

$2 \mathrm{~g} / \mathrm{kg}$ dry diet: $\mathrm{K}_{2} \mathrm{HPO}_{4} 5.0, \mathrm{KCl} 2.5, \mathrm{NaH}_{2} \mathrm{PO}_{4} .2 \mathrm{H}_{2} \mathrm{O}$

7.5, $\mathrm{Ca}\left(\mathrm{H}_{2} \mathrm{PO}_{4}\right)_{2} \cdot \mathrm{H}_{2} \mathrm{O} 5.0$

${ }^{3}$ Contains $18 \% \mathrm{P}, 22 \% \mathrm{Ca}, 1 \% \mathrm{~F}$ (product leaflet)

${ }^{4}$ L-ascorbyl-2-monophosphate-Mg protein; $18 \mathrm{MJ} / \mathrm{kg}$ dry diet) and graded levels of L-ascorbyl-2-monophosphate-Mg (AMP; 93\% purity, Showa Denko K.K., Japan) at 0, 60,180 , and $540 \mathrm{mg} / \mathrm{kg}$ dry diet (Table 1 ). Respective estimated equivalents of ascorbic acid were $0,26,77.6$, and $232.8 \mathrm{mg} / \mathrm{kg}$ dry diet. The AMP was first mixed carefully with a small quantity of the dry ingredient mixture, which was gradually increased before pouring in the rest of the ingredients. Diets were prepared as described by Catacutan et al. (2001), but the dough-like mixture was extruded (Kitchen Aid, USA) twice, initially using a 2-mm die, and the strands were manually broken into 4-6 mm lengths. As the fish size increased, the die diameter was increased to $5 \mathrm{~mm}$ and strands were broken into $8-12 \mathrm{~mm}$ lengths. Diets were oven dried at $70^{\circ} \mathrm{C}$ for $2-3 \mathrm{~h}$ and stored at $15-18^{\circ} \mathrm{C}$. There were 4-5 batches of feed preparation throughout the study. The proximate compositions of the diets were analyzed according to AOAC (2000). In a preliminary experiment with $100 \mathrm{mg}$ AMP/kg dry diet, practical test diets were steamed for $5 \mathrm{~min}$ in the laboratory and oven-dried; the diets retained $95 \%$ of the AMP after a month of storage at room temperature $\left(28-32^{\circ} \mathrm{C}\right)$. 
Growth experiment. Weaned red snapper $(13.39 \pm 0.08 \mathrm{~g})$ that had been fed a maintenance diet without vitamin $C$ supplement for four weeks were randomly distributed into twelve 650-I fiberglass tanks at 30 fish/tank. Fish in each tank were weighed in bulk every 20 days to adjust the feeding rate (4-6\% of body weight per day). Before weighing, fish were anesthetized with 100-200 ppm MS-222 (Sigma Chemical Co., St. Louis, MO). Feed was given twice daily at 09:00 and 16:30. Average weight, survival, specific growth rate (SGR), protein efficiency ratio (PER), feed conversion ratio (FCR), and hepatosomatic index (HSI) were determined after 17 weeks of feeding.

Vitamin $C$ analysis. Ascorbic acid levels in the liver and brain at the end of the 17week experimental feeding were analyzed by HPLC using a reversed-phase column (C 18, $4.6 \mathrm{~mm} \times 250 \mathrm{~mm}$ ) following the methods of Koshio et al. (1997) and Sakakura et al. (1998). The HPLC system (Japan) consisted of a column oven (Shimadzu CTO-6A, at $40^{\circ} \mathrm{C}$ ), detector (Shimadzu SPD-6AV, UV $257 \mathrm{~nm}$ ), pump (Shimadzu LC-9A), and chromatopak (Shimadzu C-R4A).

Hematocrit level determination. Hematocrit was determined at the end of the feeding study by the microhematocrit analytical method of Hesser (1960). Blood was withdrawn from the caudal artery (three fish from each treatment) into heparinized capillary tubes and centrifuged at $11,500 \mathrm{rpm}$ for $5 \mathrm{~min}$ at room temperature (about $25^{\circ} \mathrm{C}$ ).

Histopathological procedures. Liver, kidney, and muscle dissected from five fish at the start of the study and three fish from each treatment (one per replicate) at the end of feeding were fixed in Bouin's solution for $24 \mathrm{~h}$. Samples were embedded in paraffin, sectioned (4-5 um), and stained with hematoxylin and eosin (Humason, 1972). Sections were examined under a light microscope.

Statistical analysis. Data were analyzed using analysis of variance and Duncan's multiple range test in the SAS package for IBM-PC (SAS, 1988). Means were compared and differences between treatments were considered significant when $p<0.05$.

\section{Results}

The average body weight of the red snapper increased about six times after 17 weeks of feeding (Fig. 1). Growth rates were similar up to day 40, but started to slow down on day 60 in fish fed the AMP-free and 540 ppm diets. By the end of feeding, the average final weights of fish fed these treatments were significantly lower than those of fish fed the 60 or $180 \mathrm{ppm}$ diets. All fish fed the AMP-free diet were sluggish and had soft bodies and eroded hemorrhagic fins that were not observed in fish fed AMP-supplemented diets. Most fish in this treatment were scoliotic and some had bulging eyes.

The final weights and SGR of red snapper fed

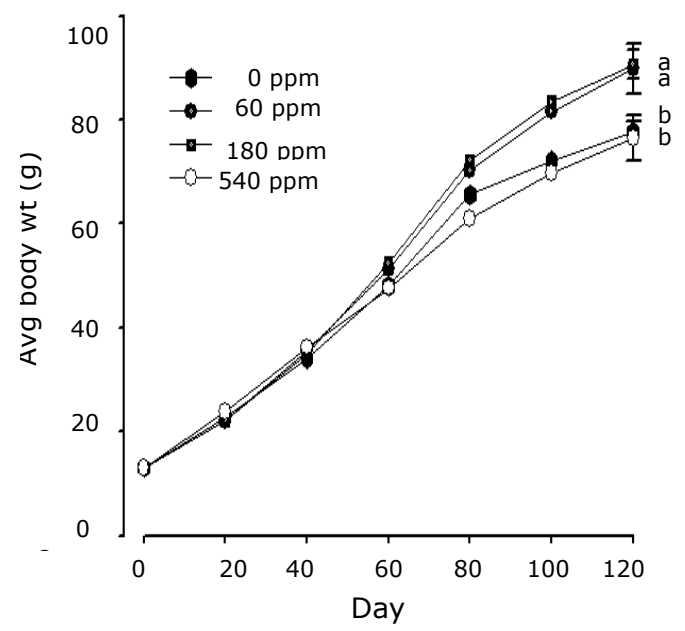

Fig. 1. Average body weight of red snapper (Lutjanus argentimaculatus) fed diets containing different levels of Lascorbyl-2-monophosphate-Mg (AMP) for 17 weeks. the 60 or $180 \mathrm{ppm}$ diet were significantly higher than those of snapper fed the 0 or 540 ppm diets (Table 2). Survival was lowest in fish fed the control, although there were no significant differences among treatments. The PER and FCR were better in red snapper fed the $60 \mathrm{ppm}$ diet than in the control, and there were no further improvements in fish fed a higher dietary level of AMP. The HSI was significantly highest in fish fed the control while blood hematocrit was significantly highest in fish fed the 60 and 180 ppm diets. Ascorbic acid in the brain and liver increased as the dietary level of AMP increased. For each dietary treatment, the brain tissue had about three times more ascorbic acid than the liver tissue. Ascorbic acid levels in the brain and liver of fish fed the $60 \mathrm{ppm}$ diet were significantly higher than in fish fed the control, but there was no significant increase when the level was raised to $180 \mathrm{ppm}$. 
Table 2. Growth, survival, feed efficiency, blood parameters, and ascorbic acid level in liver and brain tissues of red snapper (Lutjanus argentimaculatus) after 17 weeks of feeding diets with different levels of L-ascorbyl-2-monophosphate-Mg (AMP).

\begin{tabular}{|c|c|c|c|c|}
\hline & \multicolumn{4}{|c|}{ AMP content ( $\mathrm{mg} / \mathrm{kg}$ diet) } \\
\hline & 0 & 60 & 180 & 540 \\
\hline Initial wt (g) & $13.35 \pm 0.08$ & $13.43 \pm 0.10$ & $13.39 \pm 0.06$ & $13.38 \pm 0.09$ \\
\hline Final wt (g) & $77.8 \pm 2.0^{\mathrm{b}}$ & $89.9 \pm 4.9^{a}$ & $90.7 \pm 2.7^{\mathrm{a}}$ & $76.6 \pm 4.4^{b}$ \\
\hline SGR $(\% / \text { day })^{2}$ & $1.47 \pm 0.02^{\mathrm{bc}}$ & $1.58 \pm 0.04^{\mathrm{ab}}$ & $1.60 \pm 0.02^{\mathrm{a}}$ & $1.45 \pm 0.05^{c}$ \\
\hline Survival $(\%)^{1}$ & $88.9 \pm 6.8$ & $97.8 \pm 2.2$ & $97.8 \pm 2.2$ & $98.9 \pm 1.1$ \\
\hline $\mathrm{PER}^{3}$ & $0.58 \pm 0.02^{b}$ & $0.65 \pm 0.01^{\mathrm{a}}$ & $0.66 \pm 0.01^{\mathrm{a}}$ & $0.58 \pm 0.02^{b}$ \\
\hline $\mathrm{FCR}^{4}$ & $3.60 \pm 0.14^{a}$ & $3.21 \pm 0.04^{b}$ & $3.19 \pm 0.04^{b}$ & $3.62 \pm 0.10^{\mathrm{a}}$ \\
\hline HSI $(\%)^{5}$ & $1.67 \pm 0.08^{\mathrm{a}}$ & $1.41 \pm 0.05^{\mathrm{b}}$ & $1.31 \pm 0.05^{\mathrm{b}}$ & $1.37 \pm 0.05^{\mathrm{b}}$ \\
\hline Hematocrit (\%) & $45.01 \pm 5.32^{\mathrm{ab}}$ & $55.48 \pm 5.82^{\mathrm{a}}$ & $57.69 \pm 2.35^{\mathrm{a}}$ & $33.44 \pm 4.74^{\mathrm{b}}$ \\
\hline \multicolumn{5}{|c|}{ Ascorbic acid level (ug/g of wet tissue) } \\
\hline Liver & $30.4 \pm 2.3^{\mathrm{a}}$ & $55.4 \pm 0.1^{\mathrm{b}}$ & $81.7 \pm 7.3^{b c}$ & $105.4 \pm 12.5^{c}$ \\
\hline Brain & $111.0 \pm 11.7^{\mathrm{a}}$ & $237.4 \pm 3.2^{b}$ & $261.2 \pm 5.1^{\mathrm{b}}$ & $337.4 \pm 17.8^{c}$ \\
\hline
\end{tabular}

Means in a row with different superscripts significantly differ $(p<0.05)$.

${ }^{1}$ Survival $(\%)=100 \times$ (final no. of fish/initial no. fish)

${ }^{2}$ Specific growth rate (\%/day) $=100 \times$ (In avg final wt - In avg initial wt)/no. days

3 Protein efficiency ratio $=$ wt gain $(\mathrm{g}) /$ protein fed $(\mathrm{g})$

${ }^{4}$ Feed conversion ratio $=$ dry wt feed $(\mathrm{g}) /$ wet wt gain $(\mathrm{g})$

${ }^{5}$ Hepatosomatic index $=100$ (liver wt/fish body wt)

Histological analysis of the kidney and liver showed normal cellular structures at the start of the feeding (Fig. 2). At the end of feeding, the kidney of fish fed the $540 \mathrm{ppm}$ diet had extensive degeneration of the renal tubules and the intertubular tissues had

a

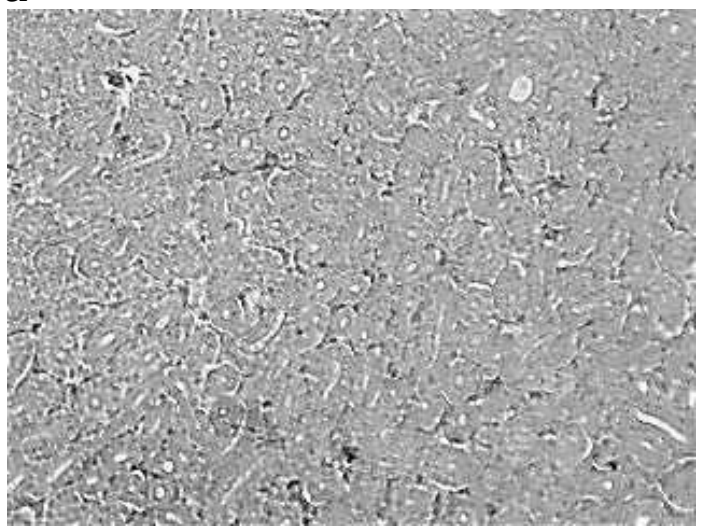

C

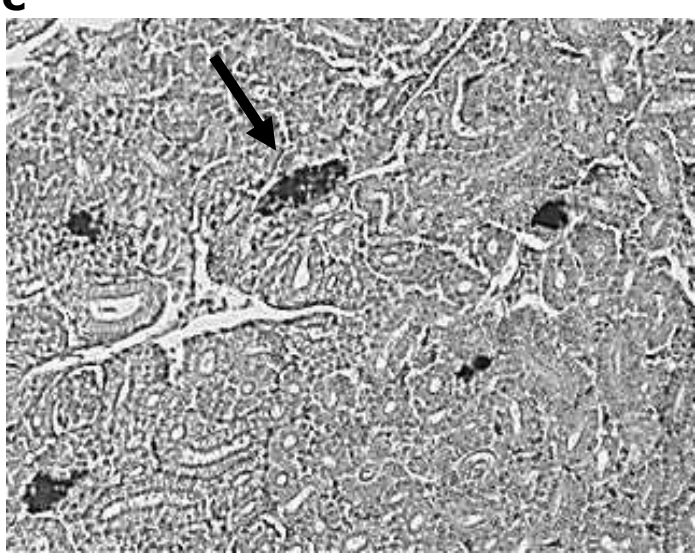

b

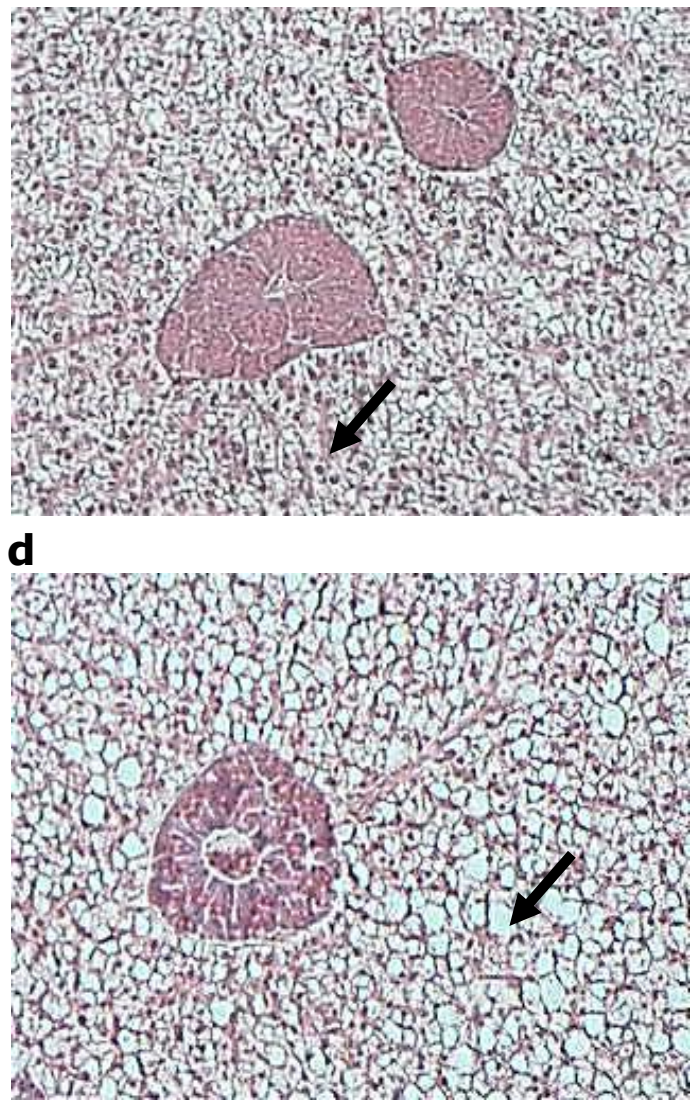

Fig. 2. Normal cellular structures in the (a) kidney and (b) liver at the start of feeding (arrow shows hepatocyte with central round nucleus. After 17 weeks of feeding, (c) extensive degeneration and necrotic changes in the renal tubules with hemosiderin (arrow) in the kidney of snapper fed the $540 \mathrm{ppm}$ diet and (d) extensive vacuolation (arrow) and necrosis of the hepatocytes in liver of snapper fed the $180 \mathrm{ppm}$ diet (H\&E). 
extensive pigment deposits. The livers and intertubular tissues of fish fed the control and $60 \mathrm{ppm}$ diets had slight vacuolation of the hepatocytes, but fish fed the 180 and 540 ppm diets had severe necrosis, extensive vacuolation, and cloudy swelling in their hepatocytes. No changes in the cellular structure of the muscle tissues were noted.

\section{Discussion}

Red snapper fed the AMP-free diet had deficiency symptoms (bulging eyes, soft body, eroding and hemorrhagic fins) similar to fish fed diets without vitamin $C$ supplement (Dabroswki et al., 1990; Shiau and Hsu, 1995). These symptoms are related to collagen malsynthesis (Moreau et al., 1996). Collagen is an important component in connective tissues. In the present study, fish fed the AMP-free diet had soft bodies not observed in the other treatments, indicating that collagen formation was hampered in this treatment. Collagen synthesis is enhanced when diets are supplemented with vitamin C (Eya, 1996: Terova et al., 1998). For the red snapper in this study, a dietary supplement of $60 \mathrm{mg}$ AMP/ $\mathrm{kg}$ diet, equivalent to $26 \mathrm{mg}$ ascorbic acid per $\mathrm{kg}$ diet, was an adequate source of vitamin $\mathrm{C}$ to prevent gross vitamin deficiency symptoms. This level is within the range that enhances collagen synthesis in channel catfish (30 mg AMP; Mustin and Lovell, 1992) while the less stable L-ascorbic acid allows optimum synthesis of vertebral collagen in the African catfish Clarias gariepinus at $46 \mathrm{mg} / \mathrm{kg}$ diet (Eya, 1996).

The final average weight, PER, and FCR of red snapper fed the $60 \mathrm{mg}$ AMP diet were significantly better than in fish fed the AMP-free diet. Increasing the AMP level to 180 or $540 \mathrm{mg}$ did not further improve growth or feed efficiency. Thus, a dietary supplement of AMP at $60 \mathrm{mg} / \mathrm{kg}$ diet in practical diet formulations for red snapper seems to be optimum for growth and feed efficiency. For sea bass and grouper, 30-60 mg AMP/kg diet (or 13$26 \mathrm{mg} \mathrm{AA} / \mathrm{kg}$ diet) is best for good growth, survival, and the prevention of vitamin C deficiency symptoms (Phromkunthong et al., 1997; Lin and Shiau, 2005). However, to avoid AA deficiency symptoms in ayu, the recommended level is higher: $47 \mathrm{mg} \mathrm{AA} / \mathrm{kg}$ diet (Xie and Niu, 2006).

Although the AMP540 diet produced the highest ascorbic acid in the examined tissues, there was a significant decrease in growth and feed efficiency of fish fed this diet. The increased dietary level of AMP seemed to have a toxic effect on the red snapper as those fed the AMP540 diet had extensive degeneration of the renal tubules, an extensive pigment deposit in the intertubular tissues, and a significantly lower final weight than fish fed the AMP 60 and AMP180 diets. Further, fish fed the AMP180 and AMP540 diets had livers with severe necrosis, extensive vacuolation, and cloudy swelling of the hepatocytes. In Atlantic salmon Salmo salar L., a diet with 5000 ppm crystalline vitamin $C$ reduced selenium (Se) in the liver (Maage et al., 1990). Fish with Se depletion are anorexic (Watanabe et al., 1997). This could explain why the red snapper in our study had significantly slower growth at $540 \mathrm{mg} \mathrm{AMP} / \mathrm{kg}$ diet in addition to the degenerative effect on the kidney. Lower levels of AMP (e.g., $100 \mathrm{mg} / \mathrm{kg}$ diet) do not cause pathological changes in the gill or kidney of small sea bass $(<5 \mathrm{~g}$; Phromkunthong et al., 1997). In the present study, the $60 \mathrm{mg}$ AMP diet enhanced the growth of the red snapper without causing pathological changes in the liver, kidney, or muscle.

The level of ascorbic acid in the red snapper liver and brain increased as the level of dietary AMP increased, as in other fish species given AMP or some form of vitamin C (Fournier et al., 2000; Lin and Shiau, 2005). The level of ascorbic acid did not plateau but continued to rise in red snapper fed the AMP540 diet, similar to ayu fed a diet containing $1176 \mathrm{mg} \mathrm{AMP} / \mathrm{kg}$ diet (Koshio et al., 1997). The brain is a vital organ and likely stores vitamin $\mathrm{C}$ longer than other tissues in case of vitamin C depletion (GouillouCoustans and Kaushik, 2001). In the present study, although the control snapper received no vitamin $C$ supplement for 21 weeks and exhibited vitamin deficiency symptoms, they had $111 \mathrm{ppm}$ ascorbic acid in the brain, more than 3 times the amount in the liver $(30 \mathrm{ppm})$. Other species given no dietary vitamin C supplement for 8-20 weeks also exhibited vitamin C deficiency symptoms and had less than 20-30 ppm ascorbic acid in the liver (Lee et al., 1998). Parrot fish Oplegnathus fasciatus $(3.9 \mathrm{~g})$ fed a vitamin-free casein-gelatin based diet retained $31.5 \mathrm{ppm}$ ascorbic acid in the brain and 
none in the muscle, liver, or gill after 11 weeks (Wang et al., 2003). In the current study, ascorbic acid was still detected in the brain and liver of snapper fed no dietary vitamin $C$ for 21 weeks, suggesting that 21 weeks may not be enough to deplete vitamin $C$ in these organs when the fish is fed a practical diet formulation. It could also indicate a difference in the rate of ascorbic acid deposition between tissues and species as noted in a parallel experiment in sea bass and sea bream Sparus aurata L. (Alexis et al., 1999).

Hematocrit of red snapper fed 60 and $180 \mathrm{mg} \mathrm{AMP} / \mathrm{kg}$ diets was significantly higher than hematocrit of fish fed the AMP540 diet. A low hematocrit level is indicative of abnormal function (Anderson and Siwicki, 1995). This was evident in snapper fed the 540 mg AMP diet. The hematocrit of channel catfish (29-42\%) fed a diet without AMP for 12 weeks was significantly lower than in those fed diets containing up to $120 \mathrm{mg} \mathrm{AMP} / \mathrm{kg}$ diet (Mustin and Lovell, 1992). In our study, the differences in hematocrit level could only be due to the different dietary levels of AMP since all fish were handled similarly and fed a basal diet for the same length of time. As such, dietary AMP at 540 ppm in practical diets for red snapper is toxic.

Snapper utilized AMP as a dietary source of vitamin C, but the toxic effect at the level of $540 \mathrm{mg} \mathrm{AMP} / \mathrm{kg}$ was evident not only in growth and feed efficiency but also in the histology of the liver and kidney. Based on the experimental conditions of this study and the practical composition of the basal diet, the minimum amount of AMP that supported optimal growth and feed efficiency without causing clinical signs of ascorbic acid deficiency was $60 \mathrm{mg} / \mathrm{kg}$ diet, equivalent to $26 \mathrm{mg}$ ascorbic acid $/ \mathrm{kg}$ diet.

\section{Acknowledgements}

The authors would like to thank Dr. Veronica Alava and Dr. Relicardo Coloso for valuable comments and Mr. Hernando Alcalde for his commendable technical assistance.

\section{References}

Alexis M.N., Nenga I., Fountoulaki E., Papoutsi E., Andriopoulou A., Koutsodimou M. and J. Gabaudan, 1999. Tissue ascorbic acid levels in European sea bass (Dicentrarchus labrax) and gilthead sea bream (Sparus aurata L.) fingerlings fed diets containing different forms of ascorbic acid. Aquaculture, 179:447-456.

Anderson A. and A. Siwicki, 1995. Basic haematology and serology for fish health programs. pp. 185-202. In: M. Shariff, J.R. Arthur, R.P. Subasinghe (eds.). Diseases in Asian Aquaculture II, Fish Health Section. Asian Fish. Soc., Manila, Philippines.

AOAC, 2000. Official Methods of Analysis, $15^{\text {th }}$ ed. K. Herlich (ed.), Assoc. Official and Analytical Chemists, Arlington, VA. 1298 pp.

Catacutan M. and G. Pagador, 2004. Partial replacement of fish meal by defatted soybean meal in formulated diets for the mangrove red snapper, Lutjanus argentimaculatus (Forsskal 1775). Aquacult. Res, 35:1-8.

Catacutan M., Pagador G. and S. Teshima, 2001. Effect of dietary protein and lipid levels on growth, survival and body composition of the mangrove red snapper, Lutjanus argentimaculatus. Aquacult. Res., 32:811-818.

Dabroswki K., El-Fiky N., Kock G., Frigg M. and W. Wieser, 1990. Requirement and utilization of ascorbic acid and ascorbic sulfate in juvenile rainbow trout. Aquaculture, 91:317-337.

Duray M.N., Alpasan L.G. and C. Estudillo, 1996. Improved hatchery rearing of mangrove red snapper, Lutjanus argentimaculatus, in large tanks with small rotifer (Brachionus plicatilis) and Artemia. Isr. J. Aquacult. - Bamidgeh, 48:123-132.

Eya J.C., 1996. 'Broken-skull disease' in African catfish Clarias gariepinus is related to a dietary deficiency of ascorbic acid. J. World Aquacult. Soc., 27:493-498.

Fournier V., Gouillou-Coustans M.F. and S.J. Kaushik, 2000. Hepatic ascorbic acid saturation is the most stringent response criterion for determining the vitamin $C$ requirement of juvenile European sea bass (Dicentrarchus labrax). J. Nutr., 130:617620. 
Gouillou-Coustans M. and S.J. Kaushik, 2001. Ascorbic acid requirement in marine and freshwater: is there a difference? pp. 49-68. In: K. Dabrowski (ed.). Ascorbic Acid in Aquatic Organisms: Status and Perspective. CRC Press, Washington DC.

Hesser E.F., 1960. Methods for routine fish haematology. Prog. Fish Cult., 22:164-171. Humason G.L., 1972. Animal Tissue Techniques, $3^{\text {rd }}$ ed. W.H. Freeman and Co., San Francisco, CA. 641 pp.

Ibarra-Castro L. and L. Alvarez-Lajonchere, 2009. Improved induced-spawning protocol for the spotted rose snapper (Lutjanus guttatus). Isr. J. Aquacult. - Bamidgeh, 61(2):121-133.

Koshio S., Sakakura, Y., Iida, Y., Tsukamoto, K., Kida, T. and K. Dabrowski, 1997. The effect of vitamin $\mathrm{C}$ on schooling behavior of amphidromous fish, ayu, Plecoglossus altivelis. Fish. Sci., 63:619-624.

Lee K.J., Kim K.W. and S.C. Bai, 1998. Effects of different dietary levels of L-ascorbic acid on growth and tissue vitamin $\mathrm{C}$ concentration in juvenile Korean rockfish, Sebastes schlegeli (Hilgendorf). Aquacult. Res., 29:237-244.

Leu M.Y., Chen I.H. and L.S. Fang, 2003. Natural spawning and rearing of mangrove red snapper, Lutjanus argentimaculatus, larvae in captivity. Isr. J. Aquacult. - Bamidgeh, 55(1):22-30.

Lin M.F. and S.Y. Shiau, 2005. Requirements of vitamin C (L-ascorbyl-2monophosphate-Mg and L-ascorbyl-2-monophosphate-Na) and its effects on immune responses of grouper, Epinephelus malabaricus. Aquacult. Nutr., 10:327-333.

Maage A., Waagbo R., Olsson P.E., Julshamn K. and K. Sandnes, 1990. Ascorbate2-sulfate as a dietary vitamin C source for Atlantic salmon (Salmo salar): 2. Effects of dietary levels and immunization on the metabolism of trace elements. Fish Physiol. Biochem., 8:429-436.

Moreau R., Kaushik S. and K. Dabrowski, 1996. Ascorbic acid status as affected by dietary treatments in the Siberian sturgeon (Acipenser baeri Brandt): tissue concentration, mobilization and L-gulonolactone oxidase activity. Fish Physiol. Biochem., 15:431-438.

Mustin W. and R.T. Lovell, 1992. Na-L-ascorbyl-2-monophosphate as a source of vitamin C for channel catfish. Aquaculture, 105:95-100.

Phromkunthong W., Boonyaratpalin $\mathbf{M}$. and V. Storch, 1997. Different concentrations of ascorbyl-2-monophosphate-magnesium as dietary sources of vitamin C for sea bass, Lates calcarifer. Aquaculture, 151:225-243.

Sakakura Y., Koshio S., Iida Y., Tsukamoto K., Kida T. and J. Blom, 1998. Dietary vitamin $\mathrm{C}$ improves the quality of yellowtail (Seriola quinquiradiata) seedlings. Aquaculture, 161:427-436.

SAS, 1998. SAS/STAT User's Guide, release 6.03. SAS Institute Inc., Cary, NC. 1028 pp.

Shiau S.Y. and T.S. Hsu, 1995. L-ascorbyl-2-sulfate has equal antiscorbutic activity as L-ascorbyl-2-monophosphate for tilapia, Oreochromis niloticus X O. aureus. Aquaculture, 133:147-157.

Terova G, Saroglia M., Papp Z.G. and S. Cecchini, 1998. Dynamics of collagen indicating amino acids, in embryos and larvae of sea bass (Dicentrarchus labrax) and gilthead sea bream (Sparus aurata), originated from broodstocks fed with different vitamin C content in the diet. Comp. Biochem. Physiol. Part A, 121:111-118.

Wang X., Kim K.W., Bai S.C., Huh M.D and B.Y. Cho, 2003. Effects of the different levels of dietary vitamin $C$ on growth and tissue ascorbic acid changes in parrot fish (Oplegnathus fasciatus). Aquaculture, 215:203-211.

Watanabe T., Kiron V. and S. Satoh, 1997. Trace minerals in fish nutrition. Aquaculture, 151:185-207.

Xie Z. and C. Niu, 2006. Dietary ascorbic acid requirement of juvenile ayu (Plecoglossus altivelis). Aquacult. Nutr., 12:151-156. 